\title{
Effects of Environmental Factors on Arsenic Fractions in Plateau Lakeside Wetland Sediments
}

\author{
Yu Jing Guo ${ }^{1,2}$, Yan Wang ${ }^{2}$, Yun Gen Liu' ${ }^{2 *}$ Lei Hou², Gui Ying Yang², \\ Meng Ying Li ${ }^{2}$, Guo Jing Wen² \\ ${ }^{1}$ Research Center of Water Science and Engineering, Southwest Forestry University, Kunming 650224, China \\ ${ }^{2}$ Research Institute of Stony Desertification, Southwest Forestry University, Kunming 650224, China
}

Received: 31 May 2017

Accepted: 27 September 2017

\begin{abstract}
The toxicity of arsenic (As) in different polluted areas and its effects on human and animal health is a big concern all over the world. Although a wetland ecosystem is a "green filter," this specific function would be impaired by high As content in wetland sediments. The distribution of As in wetland sediments and its linkages to environmental factors have not been fully explored. In this study, sediment samples $(0-10 \mathrm{~cm})$ and water samples were collected from different locations along the Yangzonghai lakeside, located in the city of Yuxi, Yunnan province of China, and were analyzed for As fractions. Results showed that As content in sediments ranged from 7.550 to $89.83 \mathrm{mg} \cdot \mathrm{kg}^{-1}$ (with a mean value of $16.11 \mathrm{mg} \cdot \mathrm{kg}^{-1}$ ). The As fractions were dominated by residual fraction (B4) (up to $62.67 \%$ ), and the mean contents from high to low were: B4 (10.10) > oxidizable fraction (B3) (2.600) > acid extractable fraction (B1) $(2.270)>$ reducible fraction (B2) (2.170). The distribution of As in sediments was mainly influenced by point-source pollution. In addition, the lack of significant correlation between As content and the different landscapes in the buffer zone of Yangzonghai lakeside indicated that the land use around the lakeside wetland (mainly non-point source pollution) may not have a significant impact on As fractions. Among environmental factors, As contents were positively $(p<0.05)$ correlated to dicalcium phosphate $\left(\mathrm{Ca}_{2}-\mathrm{P}\right)$ and octacalcium phosphate $\left(\mathrm{Ca}_{8}-\mathrm{P}\right)$. However, phosphorus distribution revealed that phosphorus in sediments was mainly caused by non-point source pollution, and thus farmland fertilizer, domestic waste, and livestock manure should be controlled. As fractions such as B1, B2, and B3 in wetland sediments were positively correlated with dissolved oxygen (DO) and redox potential (Eh), but negatively correlated to organic matter $(\mathrm{OM}), \mathrm{pH}$, and lime-type phosphorus $\left(\mathrm{Ca}_{10}-\mathrm{P}\right)$ when the upstream area was dominated by agricultural lands, indicating that these parameters may affect the release of As into sediments.
\end{abstract}

Keywords: arsenic, lakeside wetland, sediments

*e-mail: henryliu1008@163.com 


\section{Introduction}

Arsenic (As) widely exists in the environment due to natural processes (hot springs and volcanic activity) and man-made activities (industrial pollution, mining, and the use of pesticides, insecticides, herbicides, and phosphate fertilizer) [1-3]. Due to its toxicity, As affects the health of humans and animals around the world. It has caused considerable concerns, and the As pollution in the environment has been reported worldwide.

In the last few years numerous studies have been undertaken, mainly focusing on: As pollution characteristics [4-6], As hyper accumulator plants [710], effects on plant uptake and nutrition [11-14], and remediation of As contamination technology [15-16]. However, studies on As fractions in lakeside wetland sediments have seldom been reported. According to an improvement to the Community Bureau of Reference of the European Commission (BCR) sequential extraction procedure, As can be divided into four operationally defined fractions: acid extractable fraction, reducible fraction, oxidizable fraction, and residual fraction [1718]. Lakeside wetland sediment has a significant effect on the interception of exogenous pollutants, including nutrients, through particle adsorption precipitation, plant uptake, and microbial transformation, thus serving as a natural barrier to protect lake water environments. It has been reported that As contents can be attenuated when contaminated water flows through wetland areas [19]. Arsenic contamination in wetland sediments may affect wetland ecosystem function, whereas environmental factors influence As and its fractions. For example, $\mathrm{pH}$ plays a great role in the As removal and adsorption process [20-21]. It is well known that As chemical reactions are mainly $\mathrm{pH}$ dependent, and that As has exhibited strong adsorption on sediments at $\mathrm{pH}$ 4.500-7.000 [22]. Organic matter (OM) has a certain influence on sediment environments, and As adsorption capacity increases as organic matter increases [2324]. Arsenic in sediment may also be mobilized due to competitive desorption by competing anions, especially phosphorus (P) [25]. Moreover, research has found that the purification and removal of aqueous phosphate by sediments explains the difference in behavior between $\mathrm{P}$ and As [26]. Additionally, redox potential controls the As partitioning, solubility, and mobility [27].

In 2008 an arsenic pollution incident broke out in Yangzonghai, and thus As contamination risk is high. Since then, research has been carried out in lakeside wetlands. As concentration in sediments varied widely and ranged $54.86-193.29 \mathrm{mg} \cdot \mathrm{kg}^{-1}$ in October 2008 and $6.050-396.50 \mathrm{mg} \cdot \mathrm{kg}^{-1}$ in April 2010 [5-6]. Previous studies from our research groups have investigated the ecological risk assessment and pollution source identification in lakeside wetland [2829]. The average of TAs concentration was 1.840-24.37 $\mathrm{mg} \cdot \mathrm{kg}^{-1}$ in Yangzonghai in October 2015 [30]. Arsenic contamination in water has turned to sediments after its outbreak in 2008. The local government has taken measures to carry out comprehensive treatments for pollution sources, which have been controlled now. However, limited studies are available on the effects of environmental factors on arsenic fractions in lakeside sediment.

Therefore, Yangzonghai lakeside wetland was selected for this research, which mainly focused on the following points: 1) the distribution characteristics of As and $\mathrm{P}$ fractions under different human disturbances, 2) the effects of environmental factors $(\mathrm{pH}, \mathrm{OM}$, and $\mathrm{P}$ fractions in the sediment and physical indicators in the water) on As fractions, and 3) the effects of the proportion of land cover in the buffer zone on As.

\section{Materials and Methods}

\section{Study Area}

Yangzonghai lake $\left(102^{\circ} 59^{\prime}-103^{\circ} 02^{\prime} \mathrm{E}, \quad 24^{\circ} 51^{\prime}-\right.$ $24^{\circ} 58^{\prime} \mathrm{N}$ ) is located in central Yunnan Province of China at an average elevation of $1,769 \mathrm{~m}$. It is one of 9 plateau lakes in Yunnan Province and belongs to the Nanpanjiang River of the Pearl River Basin. The total width of Yangzonghai Lake is $2.500 \mathrm{~km}$, the length from north to south is $12.70 \mathrm{~km}$, the drainage area is $286 \mathrm{~km}^{2}$, the lake area is $31.90 \mathrm{~km}^{2}$, the catchment area is about $192 \mathrm{~km}^{2}$, and the average annual water storage capacity is 569.0 million $\mathrm{m}^{3}$. Supply water mainly comes from rainfall, natural rivers (Yangzong and Qixing), an artificial river (Baiyi), and groundwater. The only outlet water through the river empties into the Nanpanjiang River. Compared with other coasts, only the southern coast of the wetland ecosystem function is relatively well-protected; hence we selected the southern coast of the lake as the study area.

\section{Site Description}

We lay out 3 transects ( 3 sampling points for each transect) in the lakeside wetland in the southern coast of Yangzonghai lake. The main disturbance of the first transect is agriculture mixed with rural, and the lakeside belt has a vertical lake shore length of about $80.00 \mathrm{~m}$. The second transect is agriculture, and the lakeside belt has a vertical lake shore length of about $120.0 \mathrm{~m}$. The third is rural, and the lakeside belt has a vertical lake shore length of about $100.0 \mathrm{~m}$ (Fig. 1). Along the shore to the middle of the lake, we laid out three samples in equal proportion for each transect. The sediment samples were collected on the surface $(0-10 \mathrm{~cm})$. Field sampling was conducted in October 2015, and January, April, and July 2016. Basic properties collected are included in Table 1. Arsenic fractions used BCR sequential extraction procedure [18], TAs (by $\mathrm{HCl}-\mathrm{HNO}_{3}-\mathrm{HClO}_{4}$ digestion), OM (by potassium dichromate method), TP (by molybdenum blue colorimetric method), $\mathrm{P}$ fractions, and $\mathrm{pH}$ in the sediment, and $\mathrm{DO}, \mathrm{Eh}, \mathrm{TDS}$, and $\mathrm{pH}$ in the water were determined [31]. 


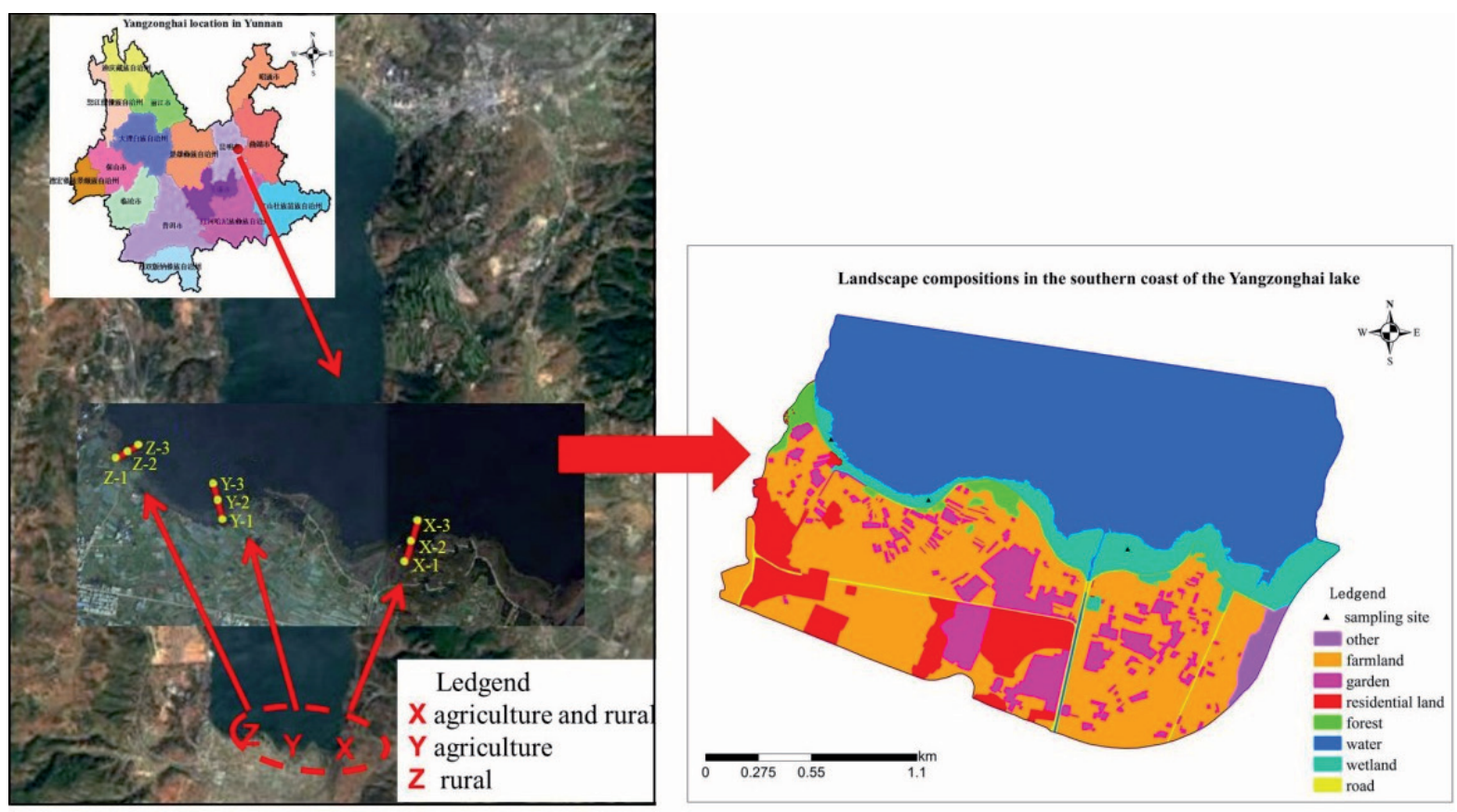

Fig. 1. Study area and distributions of sampling sites.

LANDSAT-TM images (with a resolution of $30 \mathrm{~m}$ ) and Google Earth fine resolution images were selected for the month of February 2016. According to "land use classification" (GB/T21010-2007), the study area of topographic maps and field investigation established by the field of identification, seven land use types were classified: water, wetland, forest, road, farmland, garden, and residential land. In ArcMap10.1, taking the monitoring point of lakeside wetland as the center, we generated a buffer with a radius of $50,100,150$, and $300 \mathrm{~m}$, and obtained the land use area proportional to each buffer (Fig. 1).

\section{Statistical Analysis}

Data analysis was carried out using SPSS Version 19.0. One-way analysis of variance (ANOVA) was implemented to test the differences in As fractions and environmental factors among three transects. Differences were considered significant when $\mathrm{P}<0.05$. Box diagram analysis was conducted using R.3.2.1 software. Primary component analysis (PCA) was conducted using Canoco 4.5 for Windows to show spacial distribution in order to identify the pollution sources of As and P. By explaining the correlation among a large number of variables, it is possible to reduce the dimension of the data set without losing much information [32]. In addition, Spearman correlation coefficients and redundancy analyses (RDA) were performed to identify the relationships between the concentrations of As fractions and environmental factors. Before undertaking the RDA, the $\log (x+1)$ transformation of all the data was performed to meet the data normality assumptions.

\section{Results and Discussion}

\section{Distributions of Arsenic and Phosphorus Fractions \\ Overall Spatial Distributions in Different Transects}

PCA analysis was performed to assess the relationship between the parameters associated with the three transects and the spatial distribution patterns of the sampling sites. The factor loading scores in biplots (Fig. 2) showed a clear separation among the sampling sites collected on three transects. In Fig. 2a), three main groups can be clearly identified. The PC1 and PC2 loading plot contributed 44.10 and $27.80 \%$ of the explained variance, respectively (Fig. 2a). The group was identified in transects 1-3. Transect 1 was clustered on the right side of the graph, transect 2 was clustered on the lower left quadrant, and transect 3 was clustered on the upper left quadrant. Based on the above analysis, there were obvious differences in the three transects. TP, Al-P, DTP, and calcium-bound phosphorus accumulated to a greater extent on transect 1, and Fe-P accumulated to a greater extent on transect 3. Different human interferences played important roles in shaping the spatial distribution patterns of $\mathrm{P}$ the middle of a lake fractions in these transects. Sites 15, 18, and 24 were in direction sampling, which failed to be grouped into transect 2 but were grouped in transect 3. Sites 31 and 32 failed to be grouped into transect 3 but were grouped in transect 2. This result was likely related to the spatial heterogeneity of the different human interferences and variations in the environmental conditions because 
Table 1. Indicator description.

\begin{tabular}{|c|c|c|c|}
\hline Sediment arsenic & Index & Description & Unit \\
\hline & TAs & Total arsenic & $\mathrm{mg} \cdot \mathrm{kg}^{-1}$ \\
\hline & B1 & $\begin{array}{l}\text { Acid-extractable } \\
\text { fraction }\end{array}$ & $\mathrm{mg} \cdot \mathrm{kg}^{-1}$ \\
\hline & $\mathrm{B} 2$ & Reducible fraction & $\mathrm{mg} \cdot \mathrm{kg}^{-1}$ \\
\hline & B3 & Oxidizable fraction & $\mathrm{mg} \cdot \mathrm{kg}^{-1}$ \\
\hline & B4 & Residual fraction & $\mathrm{mg} \cdot \mathrm{kg}^{-1}$ \\
\hline $\begin{array}{l}\text { Environmental } \\
\text { factors }\end{array}$ & Index & Description & Unit \\
\hline \multirow{4}{*}{ Water } & $\mathrm{pH}$ & - & - \\
\hline & DO & Dissolved oxygen & $\mathrm{mg} \cdot \mathrm{L}^{-1}$ \\
\hline & Eh & Redox potential & $\mathrm{mV}$ \\
\hline & TSS & $\begin{array}{c}\text { Conductivity in the } \\
\text { water }\end{array}$ & us $\cdot \mathrm{cm}^{-1}$ \\
\hline \multirow{10}{*}{ Sediment } & $\mathrm{pH}$ & - & - \\
\hline & $\mathrm{OM}$ & Organic matter & $\mathrm{mg} \cdot \mathrm{kg}^{-1}$ \\
\hline & $\mathrm{TP}$ & Total phosphorus & $\mathrm{mg} \cdot \mathrm{kg}^{-1}$ \\
\hline & DTP & $\begin{array}{c}\text { Dissolved total phos- } \\
\text { phorus }\end{array}$ & $\mathrm{mg} \cdot \mathrm{kg}^{-1}$ \\
\hline & $\mathrm{Ca}_{2}-\mathrm{P}$ & Dicalcium phosphate & $\mathrm{mg} \cdot \mathrm{kg}^{-1}$ \\
\hline & $\mathrm{Ca}_{8}-\mathrm{P}$ & $\begin{array}{l}\text { Octacalcium phos- } \\
\text { phate }\end{array}$ & $\mathrm{mg} \cdot \mathrm{kg}^{-1}$ \\
\hline & Al-P & $\begin{array}{l}\text { Aluminum-bound } \\
\text { phosphorus }\end{array}$ & $\mathrm{mg} \cdot \mathrm{kg}^{-1}$ \\
\hline & Fe-P & $\begin{array}{c}\text { Iron-bound phospho- } \\
\text { rus }\end{array}$ & $\mathrm{mg} \cdot \mathrm{kg}^{-1}$ \\
\hline & O-P & Occluded phosphorus & $\mathrm{mg} \cdot \mathrm{kg}^{-1}$ \\
\hline & $\mathrm{Ca}_{10}-\mathrm{P}$ & Lime-type phosphorus & $\mathrm{mg} \cdot \mathrm{kg}^{-1}$ \\
\hline
\end{tabular}

these factors could affect the distribution of $\mathrm{P}$ fractions. Therefore, $\mathrm{P}$ pollution load is mainly caused by nonpoint source pollution, and reached $34.53 \mathrm{t}$ in the south of Yangzonghai basin, where livestock and rural life were the main sources of phosphorus pollution [33].

Fig. 2b) explained $83.1 \%$ of the total variance by axes (components) 1 and 2. Transects 2 and 3 were clustered original points and, therefore, As pollution is mainly caused by point sources. Site 7 failed to be grouped in all three transects. Zhang [5] found that $82.68 \%$ of As pollution was contributed by human activities in Yangzonghai, and $\mathrm{P}$ fertilizer plant on the south bank made the greatest contribution to As accumulation in Yangzonghai lake.

\section{Distributions for Each Specific Parameter in Different Transects}

The distribution of arsenic and environmental factors along the lakeside wetland is shown in Fig. 3. TAs in sediments ranged 7.550-89.83 mg. kg ${ }^{-1}$ in transect 1; transect 2 ranged $9.820-15.43 \mathrm{mg} \cdot \mathrm{kg}^{-1}$; and transect 3 ranged $7.620-17.48 \mathrm{mg} \cdot \mathrm{kg}^{-1}$. The average values are $22.75,12.53$, and $13.05 \mathrm{mg} \cdot \mathrm{kg}^{-1}$, respectively. B1 and B3 initially decreased and then increased with the different transects; however, B2 and B4 showed a decreasing trend with the three transects. Moreover, there are no obvious differences in concentrations of As fractions among different transects $(P>0.05)$.

$\mathrm{TP}$ in sediments ranged $875.0-1,325.3 \mathrm{mg} \cdot \mathrm{kg}^{-1}$ in transect 1; transect 2 ranged $177.3-454.34 \mathrm{mg} \cdot \mathrm{kg}^{-1}$, which showed a substantial decline; and transect 3 ranged 189.2-582.6 $\mathrm{mg} \cdot \mathrm{kg}^{-1}$. The average values of transects 1-3 were $1,034.6,300.9$, and $303.0 \mathrm{mg} \cdot \mathrm{kg}^{-1}$, respectively. TP contents of transect 1 were the highest, which were significantly different from that of the other two transects $(P<0.001)$. On the other hand, the changes of
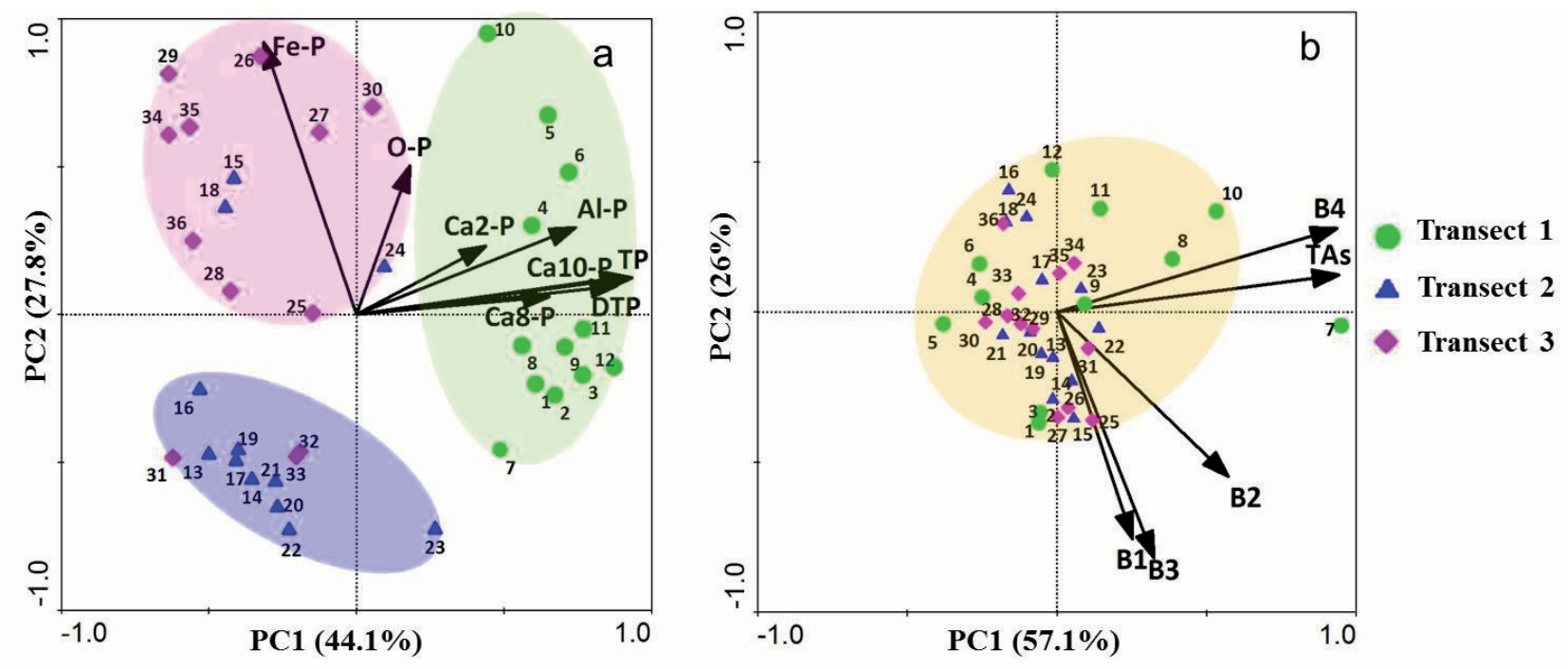

Fig. 2. Principal component analysis in three sampling transects.

Note: Phosphorus fractions a) and arsenic fractions b) of the principal component analysis in three sampling transects. 
DTP, Al-P, and $\mathrm{Ca}_{10}-\mathrm{P}$ in sediment were similar to TP. The content of transect 1 was significantly higher than that of the other two transects $(P<0.001)$. The average values described above are displayed in Table 2 . The change of $\mathrm{Ca}_{8}-\mathrm{P}$ with the three transects showed a significant initial decrease, followed by a slight increase $(P<0.01)$; Fe-P also initially decreased before increasing significantly $(P<0.05)$. The average values of $\mathrm{pH}$ in the sediments were $7.970,8.040$, and 8.030 in the three transects, respectively. There were no significant differences among these three $\mathrm{pH}$ averages. In line with $\mathrm{pH}$, the average values of $\mathrm{OM}$ were 24.03, 19.93, and $28.49 \mathrm{mg} \cdot \mathrm{kg}^{-1}$ for transects 1,2 and 3, respectively. Arsenic was the case with the variation of $\mathrm{pH}$ in sediments, there were no significant differences in $\mathrm{pH}$, DO, TDS, and Eh among the three transects (Fig. 3 and Table 2).
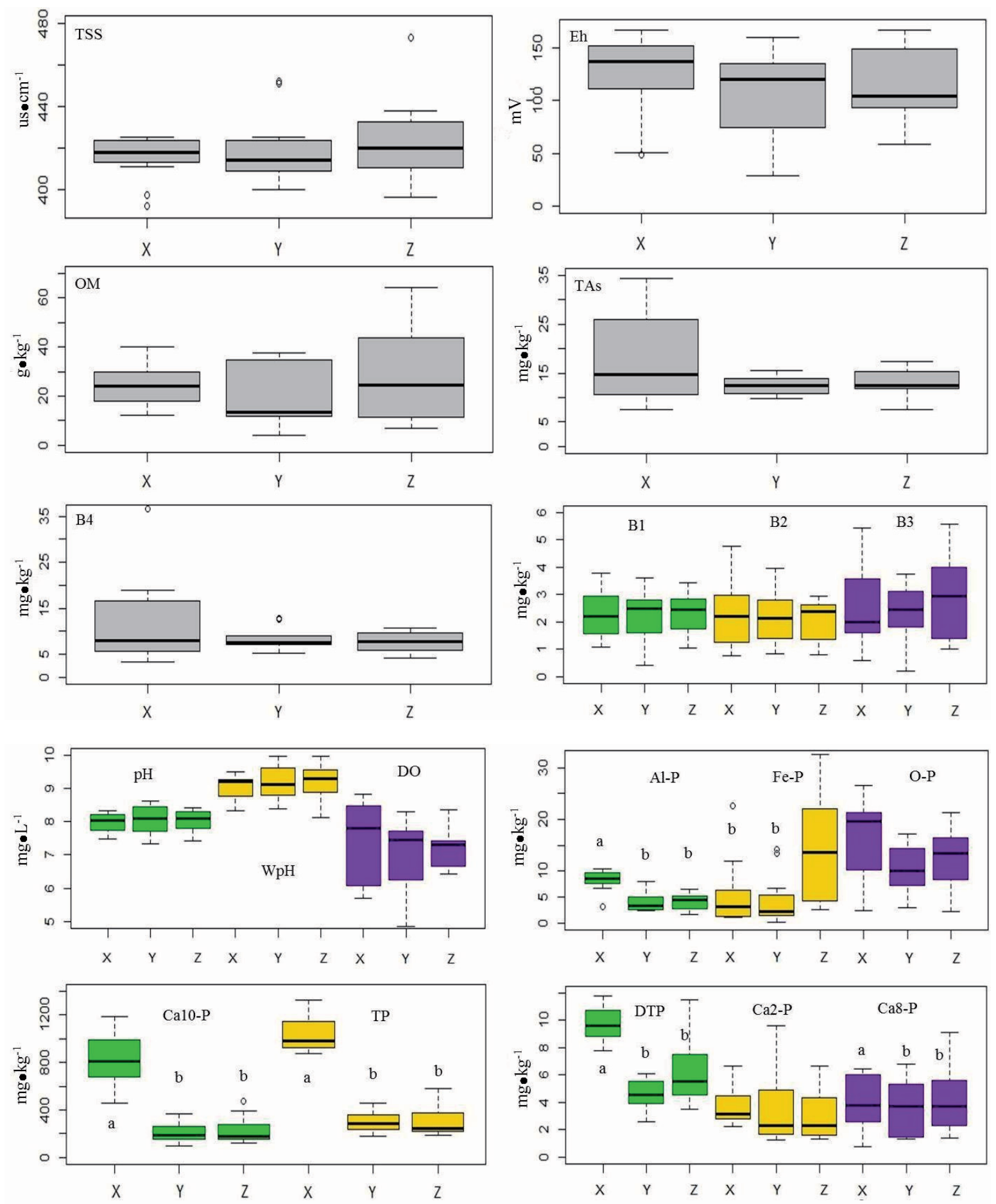

Fig. 3. Changes in arsenic and phosphorus fractions in sediments.

Note: The different letters $(a, b$, and $c)$ represent significant differences $(\mathrm{P}<0.05)$ in three sampling transects. 


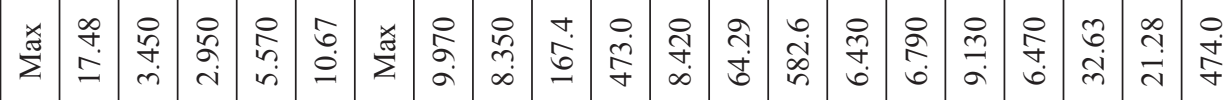

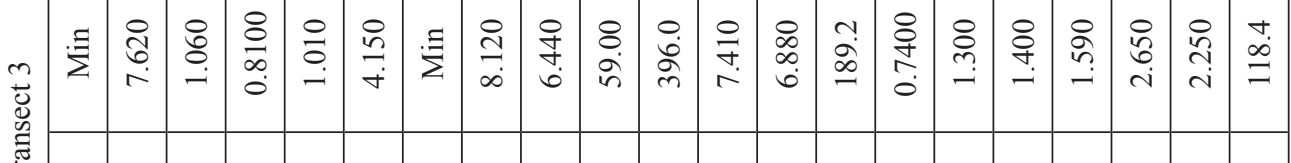

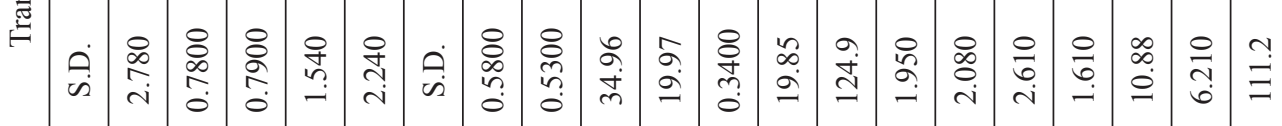

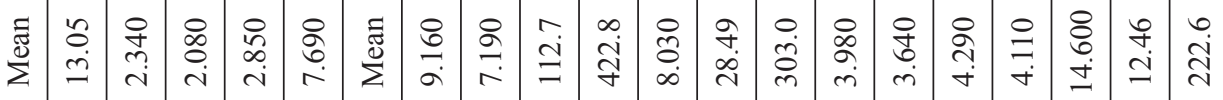

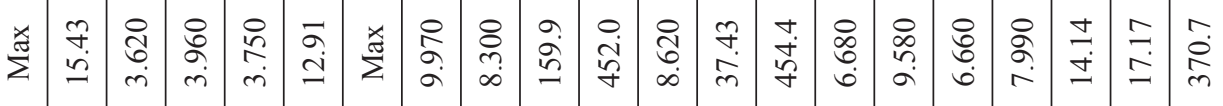

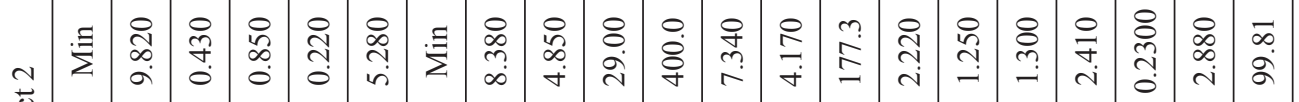
हैं

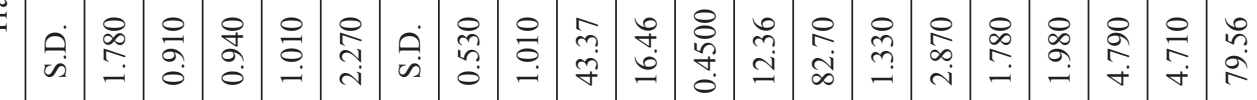

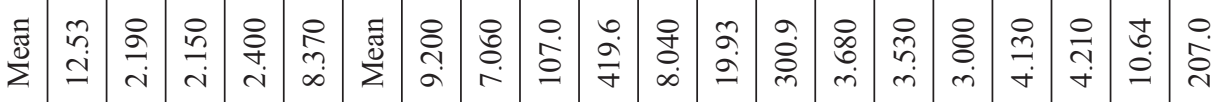

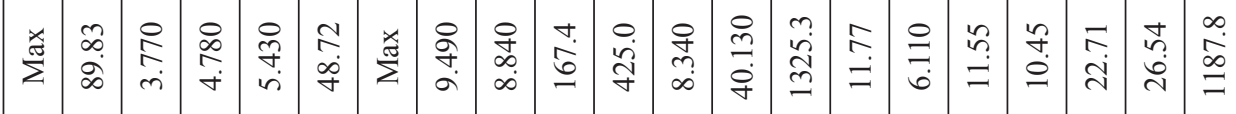

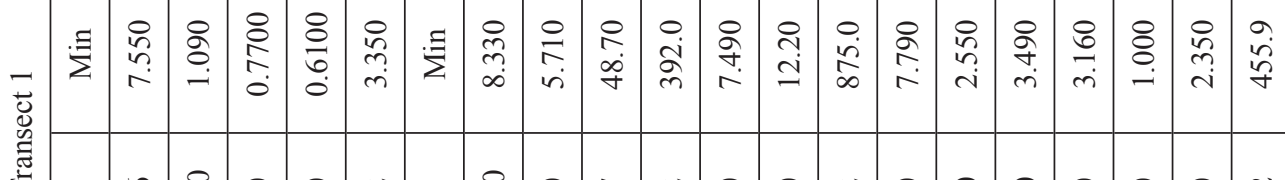

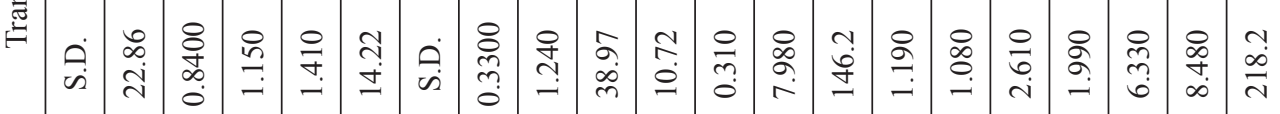

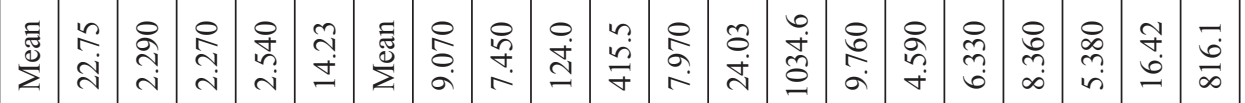

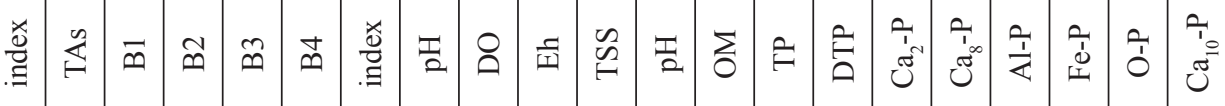


Table 3. Spearman correlations between $\mathrm{pH}, \mathrm{OM}$, and $\mathrm{P}$ fractions and arsenic fractions $(\mathrm{n}=12)$.

\begin{tabular}{|c|c|c|c|}
\hline $\begin{array}{l}\text { Arsenic } \\
\text { fractions }\end{array}$ & Transect 1 & Transect 2 & Transect3 \\
\hline TAs & $\mathrm{pH}-0.6830 *$, B4 0.9370** & $\begin{array}{c}\text { Ca2-P 0.6710*, Ca8-P 0.5800*, } \\
\text { B4 0.5800* }\end{array}$ & TP $-.8040 * *, \mathrm{WpH} 0.5940 *$ \\
\hline B1 & $\begin{array}{c}\mathrm{Ca} 10-\mathrm{P}-0.7130 * *, \mathrm{OM}-0.6220^{*}, \mathrm{DO} \\
0.8480 * *, \mathrm{OM},-0.6220^{*}, \text { Eh } 0.6870^{*}, \mathrm{~B} 2 \\
0.6220^{*}, \mathrm{~B} 30.8530^{* *}\end{array}$ & $\mathrm{OM}-0.8180 * *$, B2 $0.8950 * *$ & B2 $0.6920 *$ \\
\hline B2 & $\begin{array}{c}\text { WpH } 0.7270^{* *} \text {, DO } 0.6340^{*} \text {, Eh } 0.5850^{*} \text {, } \\
\text { B3 } 0.5870^{*}\end{array}$ & $\begin{array}{c}\mathrm{OM}-0.8110^{* *}, \mathrm{DO} 0.6010^{*}, \mathrm{~B} 3 \\
0.6080^{*}\end{array}$ & $\begin{array}{c}\text { Fe-P }-0.5870^{*}, \mathrm{pH}-0.6640^{*}, \mathrm{pH} \\
0.6080^{*}\end{array}$ \\
\hline B3 & $\begin{array}{c}\text { Ca10-P }-0.7480^{* *}, \text { DO } 0.8440^{* *}, \text { Eh } \\
0.6060^{*}\end{array}$ & B4 0.6360* & $\begin{array}{l}\text { DTP } 0.8050^{* *} \text {, Ca8-P } 0.6570^{*} \text {, O-P } \\
0.6640^{*} \text {, OM } 0.7620^{* *} \text {, Eh }-0.6220^{*}\end{array}$ \\
\hline B4 & $\mathrm{pH}-0.7250^{* *}$ & $\begin{array}{c}\text { DTP } 0.7410^{* *}, \text { Ca2-P } 0.8040^{* *}, \\
\text { Al-P } 0.6080^{*}\end{array}$ & DTP $-0.6080^{*}$ \\
\hline
\end{tabular}

Note: Only significant correlations are listed. ${ }^{* *}$ Significance at the 0.01 probability level. * Significance at the 0.05 probability level.

\section{Effects of Environmental Factors on Arsenic Fractions}

\section{Spearman Analysis of Environmental Factors and Arsenic Fractions}

Correlation analyses between environmental factors and As fractions are shown in Table 3. TAs was positively and significantly correlated to $\mathrm{Ca}_{2}-\mathrm{P}$ and $\mathrm{Ca}_{8}-\mathrm{P}$ $(P<0.5)$, but negatively and significantly correlated to TP $(P<0.01)$. Eh was positively correlated to B1, B2, and $\mathrm{B} 3$ on transects 1 and 2, while negatively correlated to B3 on transect 3. The change of As fractions easily occurs in the surface sediments of the redox conditions, resulting in rapid mobilization of As [34]. B1 was negatively related to $\mathrm{OM}$ in transects 1 and 2, while positively and significantly correlated to $\mathrm{OM}$ on transect $3(P<0.01)$. The occurrence of higher concentrations of As with increasing organic matter contents is possibly due to the formation of organ-arsenic complexes [35]. $\mathrm{B} 1, \mathrm{~B} 2$, and $\mathrm{B} 3$ were positively related to $\mathrm{DO}$ and $\mathrm{Eh}$ in transect 3. TAs and B4 were negatively related to $\mathrm{pH}$.

Phosphorus pollution is derived mainly from runoff from the catchment, soil erosion, livestock, and rural domestic sewage [36]. The upstream of transect 1 consisted of Hai Yan village plus farmland. $\mathrm{Ca}_{10}-\mathrm{P}, \mathrm{Al}-\mathrm{P}$, and $\mathrm{O}-\mathrm{P}$ were identified as the most important variables in each transect, indicating that due to the presence of arable lands, considerable amounts of fertilizer and nutrients as well as pesticides are being used in the study area.

The upstream of transect 2 is comprised of agricultural land, with agricultural non-point sources being the main cause of pollution. $\mathrm{P}$ was mainly derived from the application of phosphorus-fertilizers and organic phosphorus pesticides in agriculture [37]. Agricultural activities significantly contribute to the trace metal status of agroecosystems, which includes the application of pesticides, mineral fertilizers, fertilizer, and sewage sludge [38]. At the same time, excessive application of fertilizer nutrients can result in environmental pollution [39]. The upstream of transect 3 was Tangeying village, whose main pollution sources were rural domestic sewage. Rural waste discharge - including domestic sewage and livestock manure significantly influences phosphorus pollution load in the wetland [33]. The desorption of As was considered to play a key role in the competition for P. Phosphate shares similar physiochemical properties with inorganic As (arsenate in particular), likely producing potentially competing effects on the retention of As by sediments [40]. At the same time, As fractions may change, an aspect that requires further study. On the other hand, As contamination is derived primarily from the phosphorus fertilizer plant located in Yangzongzhen on the south bank [5].

Livestock manure can be a valuable resource for farmers to provide nutrients, improve soil structure, increase vegetation coverage, and reduce erosion potential [39]. Therefore, further study is needed to investigate how agricultural pollution can be reduced while maximizing waste from waste.

\section{Redundancy Analysis of Environmental Factors and Arsenic Fractions}

Table 4 shows the dominant environmental factors with the greatest explanatory power on each transect. $\mathrm{Ca}_{10}-\mathrm{P}$, Al-P, and O-P were the most important variables and therefore were determined in each transect. TP, DTP, Fe-P, and $\mathrm{pH}$ appeared to be more related to the As fractions in transects 1 and 3. OM, DO, and $\mathrm{pH}$ value in the water were identified as the dominant variables in transects 2 and 3 . DO and $\mathrm{pH}$ value in water, and $\mathrm{Ca}_{2}-\mathrm{P}$ were identified as the dominant variables in transect 1 . Eh was only identified in transect 2. Arsenic opposed to the front, $\mathrm{Ca}_{8}-\mathrm{P}$ and TDS were identified in transects 1 and 2. In each transect, the relationship between the dominant environmental factors and As fractions in the sediment variables is shown in Fig. 4. TAs was positively 
Table 4. Dominant environmental factors with explanatory power in 3 sampling transects based on redundancy analyses.

\begin{tabular}{|c|c|c|c|c|}
\hline $\begin{array}{c}\text { Different } \\
\text { human } \\
\text { disturbance }\end{array}$ & $\begin{array}{c}\text { Dominant } \\
\text { variable }\end{array}$ & $\begin{array}{c}\text { Single } \\
\text { factor } \\
\text { explained } \\
\text { variance } \\
(\%)\end{array}$ & $\begin{array}{l}\text { Proportion } \\
\text { of total } \\
\text { explained } \\
\text { variance } \\
(\%)\end{array}$ & P-value \\
\hline \multirow{10}{*}{ Transect 1} & pH & 43.10 & 43.10 & 0.01000 \\
\hline & $\mathrm{Ca}_{10}-\mathrm{P}$ & 27.20 & 70.20 & 0.0020000 \\
\hline & TDS & 10.30 & 80.60 & 0.0060000 \\
\hline & Al-P & 4.100 & 84.60 & 0.1520 \\
\hline & O-P & 4.200 & 88.90 & 0.1040 \\
\hline & $\mathrm{Fe}-\mathrm{P}$ & 2.900 & 91.80 & 0.2060 \\
\hline & $\mathrm{Ca}_{8}-\mathrm{P}$ & 3.000 & 94.80 & 0.1740 \\
\hline & $\mathrm{Ca}_{2}-\mathrm{P}$ & 2.300 & 97.10 & 0.1920 \\
\hline & $\mathrm{TP}$ & 1.900 & 99.00 & 0.1080 \\
\hline & DTP & 0.700 & 99.70 & 0.3060 \\
\hline \multirow{10}{*}{ Transect 2} & OM & 26.80 & 26.80 & 0.01200 \\
\hline & Al-P & 16.30 & 43.20 & 0.07200 \\
\hline & $\mathrm{Ca}_{10}-\mathrm{P}$ & 16.70 & 59.80 & 0.04200 \\
\hline & TP & 7.000 & 66.90 & 0.2260 \\
\hline & DO & 9.200 & 76.10 & 0.1680 \\
\hline & TDS & 3.200 & 79.30 & 0.4680 \\
\hline & $\mathrm{WpH}$ & 2.800 & 82.10 & 0.5340 \\
\hline & Eh & 3.800 & 86.00 & 0.5060 \\
\hline & $\mathrm{Ca}_{8}-\mathrm{P}$ & 4.800 & 90.80 & 0.4260 \\
\hline & $\mathrm{O}-\mathrm{P}$ & 6.600 & 97.40 & 0.3000 \\
\hline \multirow{10}{*}{ Transect 3} & DTP & 36.30 & 36.30 & 0.0080000 \\
\hline & $\mathrm{pH}$ & 12.60 & 48.90 & 0.1080 \\
\hline & Al-P & 14.30 & 63.20 & 0.04600 \\
\hline & O-P & 12.90 & 76.00 & 0.04000 \\
\hline & TP & 11.80 & 87.80 & 0.002000 \\
\hline & $\mathrm{OM}$ & 3.200 & 91.00 & 0.1700 \\
\hline & Fe-P & 3.600 & 94.60 & 0.0880 \\
\hline & DO & 1.900 & 96.50 & 0.2700 \\
\hline & $\mathrm{Ca}_{10}-\mathrm{P}$ & 1.600 & 98.20 & 0.2420 \\
\hline & $\mathrm{WpH}$ & 1.300 & 99.50 & 0.2960 \\
\hline
\end{tabular}

and significantly correlated to $\mathrm{pH}$ value in water and Eh, TDS, pH value, TP, and OM. On the other hand, it had a negative relationship with various $\mathrm{P}$ fractions, $\mathrm{pH}$ value, and $\mathrm{OM}$ in transect 1 . Contrary to transect 1 , TAs had a positive correlation with various $\mathrm{P}$ fractions in transect 2. However, the effects of these indices on TAs were smaller than those of As fractions. Note that $\mathrm{TP}, \mathrm{Ca}_{10}-\mathrm{P}$, and DO were negatively correlated to TAs in each transect. Arsenic in sediments was found in the suspended colloid, which is easily extracted by alkaline aqueous solution [41] due to the fact that colloid charge varies according to the change of $\mathrm{pH}$ [42]. In our study, $\mathrm{pH}$ value in sediments was negatively correlated to TAs, $\mathrm{B} 2$, and $\mathrm{B} 4$; however, $\mathrm{pH}$ value in water was positively correlated to TAs and B2. Four fractions of As (B1, B2, B3, and B4) depend on the ionic environment and $\mathrm{pH}$ [16]. $\mathrm{Ca}_{8}-\mathrm{P}$ was positively correlated to TAs and its fractions. $\mathrm{P}$ release was positively correlated to $\mathrm{B} 1$ [43]. On the other hand, Fe-P was positively correlated to B2. Fe oxides are a major sorbent of As in sediment [44]. Sefaur and Ashim (2013) showed that As solubility, retention, and release in submerged soil was significantly influenced by the Fe-oxide minerals [45].

In addition, soil properties such as clay content and poor crystalline, iron oxides also affect the release of As into soil solutions [46-47]. Therefore, in the future we will further study the factors affecting As fractions from the aspects of soil properties, clay content, and so on.

\section{Effects of Land Use on Arsenic Fractions}

The change of land cover indirectly affects the biological, chemical, and physical processes of the soil, and a large number of studies have shown that the land cover will significantly affect the water quality of the river or riparian zone [48]. Few studies have investigated the relationship between land cover and As fractions in lakeside wetland.

\section{Land Use Structure in Buffer Zone}

We considered the 50.00, 100.0, 150.0, and $300.0 \mathrm{~m}$ buffers in the lakeside wetland in order to understand the differences of the land cover types (Fig. 5). Apparently, with the expansion of the buffer zone, land use proportion generates significant differences. With the increase of the buffer distance, the value of the percentage of wetland decreases. The lowest value was $23.02 \%$ in the $300.0 \mathrm{~m}$ buffer zone. The proportion of farmland reached $22.80 \%$ in the $300.0 \mathrm{~m}$ buffer zone, showing that the existence of a large number of wetlands were developed and utilized within this area. Compared to the $100 \mathrm{~m}$ buffer, the proportion of the water bodies reached the maximum in the $300.0 \mathrm{~m}$ buffer zone, which was unsurprising. Additionally, the proportions of forest in the $50.00,100.0,150.0$, and $300.0 \mathrm{~m}$ buffer zones were $0.03000,4.440,1.240$ and $20.44 \%$, respectively. Similar to farmland, the value of the garden proportion was highest at approximately $69.80 \%$ in the $300.0 \mathrm{~m}$ buffer, with the residential and road area accounting for only a very small proportion.

\section{Effects of Land Use on Arsenic Fractions in Buffer Zone}

The correlation between land use and As fractions is shown in Table 5. Wetland percentage was positively 

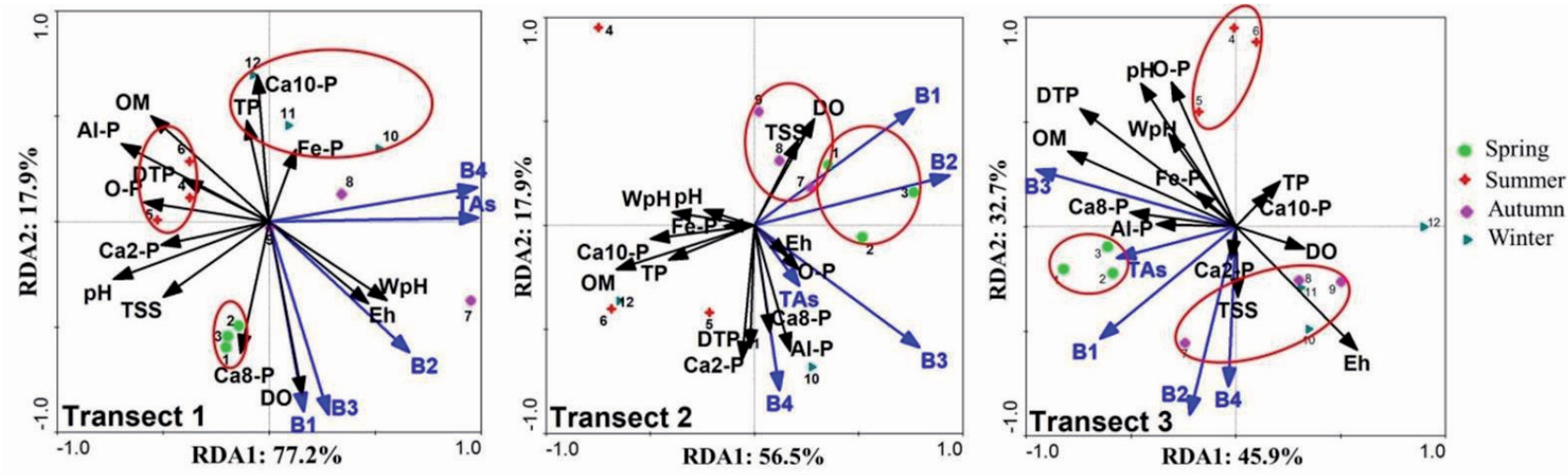

Fig. 4. Redundancy analysis showing the correlations between arsenic fractions and environment factors in three sampling transects.

correlated to B2 and B4; while, water, farmland, and garden percentages were negatively correlated to B2, which is consistent with the results of redundancy analysis (Fig. 6). Based on the RDA results, there was no correlation between buffer zone and As fractions. Riparian buffers are considered to play a major role in the process of material exchange between aquatic and terrestrial ecosystems, which is regarded as a land/ water transition. It is acknowledged that riparian buffer landscape pattern has an important impact on aquatic ecosystems [49-50]. However, in our study, it is observed that the relationships between As fractions and land use proportion were weaker in the buffer zone (Fig. 6). Alberti and Booth (2007) found that it was not possible to determine whether land use patterns changed with scale using the catchment landscape characteristics. The relationship between land use and As fractions in sediments is complicated, and is affected by a variety of factors [48].

In addition, compared with other land use types, wetland, water, and farmland percentages are strongly correlated to As fractions. In particular, wetland percentage was positively correlated to As fractions. From the point of view of landscape, the design of

Table 5. Correlation analysis of land use structure and arsenic fractions.

\begin{tabular}{|c|c|c|c|c|c|c|c|c|}
\hline & & Wetland & Water & Forest & Farmland & Road & Resident & Garden \\
\hline \multirow{5}{*}{$50 \mathrm{~m}$} & TAs & 0.6325 & -0.6325 & 0.0000 & -0.6325 & 0.0000 & & \\
\hline & B1 & 0.5798 & -0.5798 & 0.2739 & -0.5798 & 0.2739 & & \\
\hline & B2 & $0.7379 *$ & $-0.7379 *$ & -0.3651 & $-0.7379 *$ & -0.3651 & & \\
\hline & B3 & 0.5270 & -0.5270 & 0.0000 & -0.5270 & 0.0000 & & \\
\hline & B4 & $0.6852 \%$ & $-0.6852 *$ & 0.2739 & $-0.6852 *$ & 0.2739 & & \\
\hline \multirow{5}{*}{$100 \mathrm{~m}$} & TAs & 0.3162 & -0.3162 & 0.0000 & -0.6325 & 0.0000 & -0.5477 & -0.3162 \\
\hline & B1 & 0.05270 & -0.0527 & 0.2739 & -0.5798 & 0.2739 & -0.6390 & -0.0527 \\
\hline & B2 & $0.6852 *$ & $-0.6852 *$ & -0.3651 & $-0.7379 *$ & -0.3651 & -0.4564 & $-0.6852 *$ \\
\hline & B3 & 0.2635 & -0.2635 & 0.0000 & -0.5270 & 0.0000 & -0.4564 & -0.2635 \\
\hline & B4 & 0.1054 & -0.1054 & 0.2739 & $-0.6852 *$ & 0.2739 & $-0.7303 *$ & -0.1054 \\
\hline \multirow{5}{*}{$150 \mathrm{~m}$} & TAs & 0.6352 & -0.3162 & 0.0000 & -0.3162 & 0.3162 & -0.5477 & -0.6325 \\
\hline & B1 & 0.5798 & -0.0527 & 0.2739 & -0.0527 & 0.5270 & -0.6390 & -0.5798 \\
\hline & B2 & $0.7379 *$ & $-0.6852 *$ & -0.3651 & $-0.6852 *$ & 0.0527 & -0.4564 & $-0.7379 *$ \\
\hline & B3 & 0.5270 & -0.2635 & 0.0000 & -0.2635 & 0.2635 & -0.4564 & -0.5270 \\
\hline & B4 & $0.6852 *$ & -0.1054 & 0.2739 & -0.1054 & 0.5798 & $-0.7303 *$ & $-0.6852 *$ \\
\hline \multirow{5}{*}{$300 \mathrm{~m}$} & TAs & 0.6325 & -0.3162 & -0.6325 & -0.3162 & 0.3162 & -0.3162 & -0.3162 \\
\hline & B1 & 0.5798 & -0.5270 & -0.5798 & -0.0527 & 0.5270 & -0.5270 & -0.0527 \\
\hline & B2 & 0.7379* & -0.0527 & $-0.7379 *$ & $-0.6852 *$ & 0.0527 & -0.0527 & $-0.6852 *$ \\
\hline & B3 & 0.5270 & -0.2635 & -0.5270 & -0.2635 & 0.2635 & -0.2635 & -0.2635 \\
\hline & B4 & $0.6852 *$ & -0.5798 & $-0.6852 *$ & -0.1054 & 0.5798 & -0.5798 & -0.1054 \\
\hline
\end{tabular}




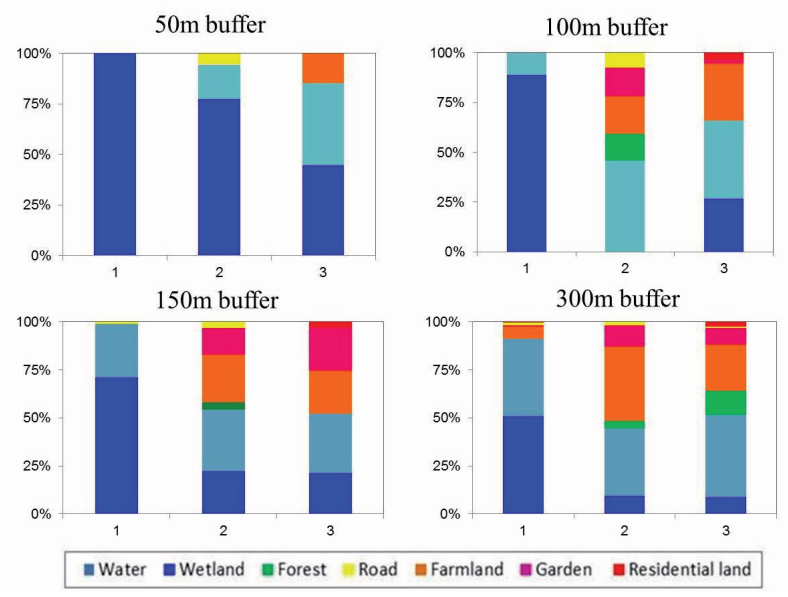

Fig. 5. Landscape compositions in Yangzonghai lakeside wetland in $50,100,150$ and $300 \mathrm{~m}$ buffer zones.

buffers is not only related to the types of land use, but also depends on the spatial structure of the landscape [48]. In order to undertake a detailed design of the buffer zone in the lakeside zone, it is necessary to study the effect of land cover on the distribution of As in lakeside wetland from the perspective of the whole basin. Besides, vegetated riparian buffers as narrow as $15 \mathrm{~m}$ can significantly reduce impacts from sediment and nutrient runoff [51-52]. Therefore, we should strengthen the vegetation construction of lakeside wetland and design of riparian buffer zones in Yangzonghai Lake.

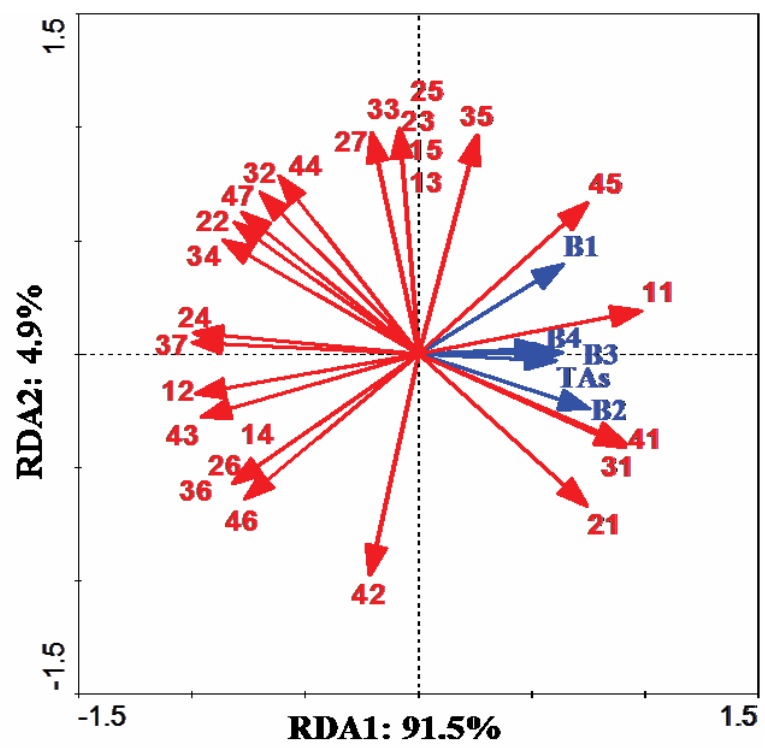

Fig. 6. Redundancy analysis for linking land use structure and arsenic fractions.

Note: The number represents the proportional land area (\%) in different buffer zones. The first $1^{*}, 2^{*}, 3^{*}$, and $4 *$ refer to 50 , 100,150 , and $300 \mathrm{~m}$ buffer zones, respectively; $* 1, * 2, * 3, * 4$, $* 5, * 6$, and $* 7$ refer to proportional land areas $(\%)$ of wetland, water, forest, farmland, road, residential land, and garden.

\section{Conclusions}

The difference of the fractions of As and $\mathrm{P}$ were caused by different human upstream disturbances. TAs in sediments under the mixed rural and agricultural disturbances is high, ranging $7.550-89.83 \mathrm{mg} \cdot \mathrm{kg}^{-1}$. However, for the separate agricultural and rural disturbance categories, the range was only 9.820-15.43 and 7.620-17.48 mg.kg-1, respectively. Phosphorus fractions, $\mathrm{pH}, \mathrm{OM}$, and Eh had significant effects on As fractions. The proportion of land use in the buffer area of lakeside wetland did not show a significant relationship to As fractions, but the wetland proportion was positively correlated to As fractions.

\section{Acknowledgements}

This research was supported by the National Natural Science Foundation of China (51469030, 31560237, and 31560147). We are grateful to research associate Hang Wang for providing useful suggestions for exprimental design and English writing.

\section{References}

1. BUNDSCHUH J., BHATTACHARYA P., SRACEK O., MELLANO M.F., RAMIREZ A.E., STORNIOLO A.R., MARTIN R.A., CORTES J., LITTER M.I., JEAN J.S. Arsenic removal from groundwater of the Chaco-Pampean plain (Argentina) using natural geological materials as adsorbents. J. Environ. Sci. Health, 46, 1297, 2011.

2. MONDAL P., MAJUMDER C.B., MOHANTY B. Laboratory based approaches for arsenic remediation from contaminated water: recent developments. J. Hazard. Mater, 137, 464, 2006.

3. SMEDLEY P.L., NICOLLI H.B., MACDONALD D.M.J., Barrosb A.J, Tullioc J.O. Hydro geochemistry of arsenic and other inorganic constituents in ground waters from La Pampa, Argentina. Appl. Geochem, 17 (3), 259, 2002.

4. ZHANG L.K., QIN X.Q., TANG J.S., LIU W., YANG H. Review of arsenic geochemical characteristics and its significance on arsenic pollution studies in karst groundwater, Southwest China. Applied Geochemstry, 77: 80, 2017.

5. ZHANG Y.X., XIANG X.P., ZHANG Y., CHEN X., LIU J.T., WANG J.C., ZHANG Y.J., SUN J.C. Distribution and sources of arsenic in Yangzonghai Lake, China. Environ. Sci, 33 (11), 3768, 2012 [In Chinese with English Abstract].

6. WANG Z.H., He B. PAN X.J., ZHANG K.G., WANG C., SUN Q., YUN Z.J., JIANG G.B. The levels, trends and risk assessment of arsenic pollution in Yangzonghai Lake, Yunnan. Sci. Sin. Chim, 43 (3), 556, 2011.

7. FU J.W., LIU X., HAN Y.H., MEI H.Y., CAO Y., DE OLIVEIRA L.M., LIU Y.G., RATHINASABAPATHI B., CHEN Y.S., MA L.Q. Arsenic-hyperaccumulator Pteris vittata efficiently solubilized phosphate rock to sustain plant growth and As uptake. Journal of Hazardous Materials, 330: 68, 2017.

8. HAN Y.H., FU J.W., XIANG P., CAO X., RATHINASABAPATHI B., CHEN Y.S., MA L.Q. Arsenic and phosphate rock impacted the abundance and diversity 
of bacterial arsenic oxidase and reductase genes in rhizosphere of As-hyperaccumulator Pteris vittata. Journal of Hazardous Materials, 321, 146, 2017.

9. HAN Y.H., FU J.W., CHEN Y.S., RATHINASABAPATHI B., MA L.Q. Arsenic uptake, arsenite efflux and plant growth in hyperaccumulator Pteris vittata: Role of arsenicresistant bacteria. Chemoshere, 144: 1937, 2016.

10. LIU X., FU J.W., SLIVA E., SHI X.X., CAO Y., RATHINASABAPATHI B., CHEN Y.S., MA L.Q. Microbial siderophores and root exudates enhanced goethite dissolution and Fe/As uptake by As-hyperaccumulator Pteris vittata. Environment Pollution, 223, 230, 2017.

11. SYU C.H., LEE C.H., JIANG P.Y., CHEN M.K., LEE A.Y. Comparison of As sequestration in iron plaque and uptake by different genotypes of rice plants grown in Ascontaminated paddy soils. Plant Soil, 374, 411, 2014

12. CARBONELL A.A., AARABI M.A., DELAUNE R.D., GAMBRELL R.P., PATRICK W.H. Bioavailability and uptake of arsenic by wetland vegetation: Effects on plant growth and nutrition. J. ENVIRON. SCI. HEALTH, A33 (1), 45, 1998.

13. MEHARG A.A., HARTLEY-WHITAKER J. Arsenic uptake and metabolism in arsenic resistant and nonresistant plant species. New Phytologist, 154 (1), 29, 2002.

14. CARBONELL A.A., AARABI M.A., DELAUNE R.D., GAMBRELL R.P., PATRICK JR W.H. Arsenic in wetland vegetation: Availability, phytotoxicity, uptake and effects on plant growth and nutrition. The Science of the Total Environment, 217, 189, 1998.

15. GARCIA-CARMONA M., ROMERO-FREIRE A., SIERRA ARAGON M., MARTINEZ GARZON F.J., MARTIN PEINADO F.J. Evaluation of remediation techniques in soils affected by residual contamination with heavy metals and arsenic. Journal of Environmental Management, 191, 228, 2017.

16. SINGH R., SINGH S., PARIHAR P., SINGH V.P., PRASADA S.M. Arsenic contamination, consequences and remediation techniques: A review. Ecotoxicology and Environmental Safety, 112, 247, 2015.

17. URE A.M., QUEVAUVILlER P., MUNTAU H., GRIEPINK B. Speciation of heavy metals in soils and sediments. An account of the improvement and harmonization of extraction techniques undertaken under the auspices of the BCR of the commission of the European Communities. Int. J. Environ. Anal. Chem, 51, 135, 1993.

18. RAURET G., LOPEZ-SANCHEZ J.F., SAHUQUILLO A., RUBIO R., DAVIDSON C., URE A., QUEVAUVILLER P. Improvement of the BCR three step sequential extraction procedure prior to the certification of new sediment and soil reference materials. J. Environ. Monit, 1, 57, 1999.

19. PERCIVAL J.B., KWONG Y.T.J., DUMARESQ C.G., MICHEL F.A. Transport and Attenuation of Arsenic, Cobalt and Nickel in an Alkaline Environment (Cobalt, Ontario). Geological Survey of Canada Open File, 1680: 30, 2004.

20. TANBOONCHUY V., HSU J.C., GRISDANURAK N., LIAO C.H. Gas-bubbled nano zerovalent iron process for high concentration arsenate removal. J. Hazard. Mater, 186, 2123, 2011.

21. SOFIA TRESINTSI K.S., VOURLIAS G., STAVROPOULOS G., MITRAKAS M. Kilogram-scale synthesis of iron oxy-hydroxides with improved arsenic removal capacity: study of $\mathrm{Fe}(\mathrm{II})$ oxidation-precipitation parameters. Water Res, 46, 5255, 2012.

22. WANG S.L., LIN C.Y., HE M.C., LIU X.T., LIU A.Q. Arsenic Distribution and Adsorption Behavior in the
Sediments of the Daliao River System in China. Water Environment Research, 85 (8), 687, 2013.

23. EICHE E., BERG M., HOENIG S.M., NEUMANN T., LAN V.M., PHAM T.K. T., PHAM H.V. Origin and availability of organic matter leading to arsenic mobilisation in aquifers of the Red River Delta, Vietnam. Applied Geochemistry, 77 (SI), 184, 2017.

24. LIAO L.B., JEAN J.S., CHAKRABORTY S., LEE M.K., KAR S., YANG H.J., LI Z. H. Hydrogeochemistry of Groundwater and Arsenic Adsorption Characteristics of Subsurface Sediments in an Alluvial Plain, SW Taiwan. Sustainability, 8 (12), 1305, 2016.

25. SILVA J., DE MELLO J.W.V., GASPARON M., ABRAHAO W.A.P. Effects of competing anions and iron bioreduction on arsenic desorption. Water Air Soil Pollut, 223, 5707, 2012.

26. PULLEY S., FOSTER I., ANTUNES P. The dynamics of sediment-associated contaminants over a transition from drought to multiple flood events in a lowland UK catchment. Hydrol Process, 30, 704, 2016.

27. SIGNES-PASTOR A., BURLO F., MITRA K., CARBONELL-BARRACHINA A.A. Arsenic biogeochemistry as affected by phosphorus fertilizer addition, redox potential and $\mathrm{pH}$ in a west Bengal (India) soil. Geoderma, 137, 504, 2007.

28. WANG S.J., LIU Y.G., HOU L., LIANG Q.B., WANG Y., ZHAN N.C., ZHANG H.J. Water environmental quality evaluation in Yangzonghai lakeside wetland based on Nemerow index. Environmental Pollution \& Control, 38 (8), 6, 2016 [In Chinese with English Abstract].

29. ZHANG H.J., LIU Y.G., LIANG Q.B., WANG Y., HOU L., ZHAN N.C., WANG S.J. Pollution evaluation and source identification of heavy metals in sediments of Yangzonghai. Environmental Science \& Technology, 39 (S1), 353, 2016 [In Chinese with English Abstract].

30. LI M.Y., ZHENG Y, LIU Y.G., HOU L., WANG Y., LIANG Q.B. Effects of arsenic and organic matter on the speciation of phosphorus in the sediments of Yangzonghai lakeside wetland. Journal of Agro-Environment Science, 35 (11), 2171, 2016 [In Chinese with English Abstract].

31. LU R.K. Soil Agrochemical Analysis Methods, China Agriculture Science and Technology Press. Beijing, 102129, 2000 [In Chinese with English Abstract].

32. KANNEL P.R., LEE S.H., KANEL S.R., KHAN S.P. Chemometric application in classification and assessment of monitoring locations of an urban river system, Anal. Chim. Acta 582, 390, 2007.

33. WEN G.J., WANG Y., LIU Y.G., ZHANG C., HOU L., GUO Y.J. Contribution of Rural and agricultural sources to aquatic phosphor load in South of Yangzong River basin. Journal of Southwest Forstry University, 37 (1), 123, 2017[In Chinese with English Abstract].

34. KWONG Y.T.J., BEAUCHEMIN M.F., HOSSAIN W.D. Gould Transformation and mobilization of arsenic in the historic Cobalt mining camp, Ontario, Canada. Journal of Geochemical Exploration, 92, 133, 2007.

35. PIKARAY S, BANERJEEM S, MUKHERJI S. Sorption of arsenic onto Vindhyan shales: role of pyrite and organic carbon. Curr Sci, 88 (10), 1580, 2005.

36. CHEN H.Y., TENG Y.G., WANG J.S. Load estimation and source apportionment of nonpoint source nitrogen and phosphorus based on integrated application of SLURP model, ECM, and RUSLE: a case study in the Jinjiang River, China. Environ Monit Assess, 185, 2009, 2013.

37. MOGHADDAS N.H., NAMAGHI H.H., GHORBANI H., DAHRAZMA B. The effects of agricultural practice 
and land-use on the distribution and origin of some potentially toxic metals in the soils of Golestan province, Iran. Environ Earth Sci, 68: 487, 2013.

38. KABATA-PENDIAS A, MUKHERJEE A.B. Trace elements from soil to human. Springer, Berlin. 2007.

39. KNOWLTON K.F., COBB T.D. ADSA foundation scholar award: Implementing waste solutions for dairy and livestock farms. Journal of Dairy Science, 89 (5), 1372, 2006.

40. SUN Q, DING S.M., ZHANG L.P., CHEN M.S.,ZHANG C.S..A millimeter-scale observation of the competitive effect of phosphate on promotion of arsenic mobilization in sediments. Chemosphere, 180, 285, 2017.

41. SMEDLEY P.L., NICOLLI H.B., MACDONALD D.M.J., BARROS A.J., TULLIO J.O. Hydro geochemistry of arsenic and other inorganic constituents in groundwaters from La Pampa, Argentina. Appl. Geochem, 17 (3), 259, 2002.

42. SADIQ M. Arsenic chemistry in soils: an overview of thermodynamic predictions and field observations. Water Air Soil Pollut, 93 (1-4), 117, 1997.

43. MORENO-JIMENEZ E., PENALOSA J.M., ESTEBANA E., BERNAL M.P. Feasibility of arsenic phytostabilisation using Mediterranean shrubs: impact of root mineralization on As availability in soils. Journal of Environmental Monitoring, 11, 1375, 2009.

44. WANG S.L., LIN C.Y., HE M.C., LIU X.T., LIU S.Q. Arsenic Distribution and Adsorption Behavior in the Sediments of the Daliao River System in China. Water Environment Research, 85 (8), 687, 2013.

45. RAHAMAN S., SINHA A.C. Water regimes: an approach of mitigation arsenic in summer rice (Oryza sativa L.) under different topo sequences on arsenic-contaminated soils of Bengal delta. Paddy Water Environ, 11, 397, 2013.

46. BHATTACHARYA B.P., SAMAL A.C., MAJUMDAR J, SANTRA S.C. Accumulation of arsenic and its distribution in rice plants (Oryza sativa L.) in Gangetic West Bengal, India. Paddy Water Environ, 8, 63, 2010.

47. BOGDAN K., SCHENK M.K. Evaluation of soil characteristics potentially affecting arsenic concentration in paddy rice (Oryza sativa L.). Environ Pollut, 157, 2617, 2009.

48. SHEN Z.Y., XIAO S.H., WEN L., AINI G., LEI C., YONG W.G. Impact of landscape pattern at multiple spatial scales on water quality: A case study in a typical urbanised watershed in China. Ecological Indicators, 48, 417, 2015.

49. ALBERTI M., BOOTH D., HILL K., COBURN B., AVOLIO C., COE S., SPRIANDELli D. The impact of urban patterns on aquatic ecosystems: an empirical analysis in Puget lowland sub-basins. Landscape Urban Planning, 80 (4), 345, 2007.

50. SLIVA L., DUDLEY WILLIAMS D. Buffer zone versus whole catchment approaches to studying land use impact on river water quality. Water Res, 35 (14), 3462, 2001.

51. CASTELLE A.J., JOHNSON A.W., CONOLLY C. Wetland and stream buffer size requirements - a review. J Environ Qual, 23, 878, 1994.

52. WENGER S. A review of the scientific literature on riparian buffer width, extent and vegetation. For the Office of Public Service and Outreach, Institute of Ecology, University of Georgia, Athens, 59, 1999. 